\title{
RECENZJE
}

Krzysztof Gawlikowski

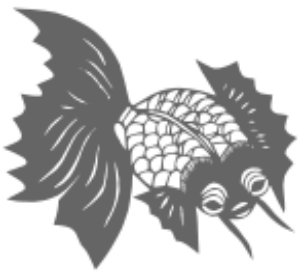

\section{AZJA WSCHODNIA W NOWYM ATLASIE ŚWIATA}

Wielki encyklopedyczny atlas świata, t. 7, Azja Wschodnia, str. 96; t. 8, Azja Poludniowa, str. 96, Gazeta Wyborcza - PWN, Warszawa 2006.

Pojawiła się na naszym rynku publikacja bardzo potrzebna i użyteczna - nowy atlas świata o charakterze encyklopedycznym. Jako inicjatywa jednej z najpopularniejszych polskich gazet ma ona nawet szansę na autentyczne zawędrowanie ,pod strzechy” polskich domostw, przynajmniej inteligenckich. Pomysł był bezsprzecznie znakomity, a firma Wydawnictwa Naukowego PWN pozwalała spodziewać się czytelnikowi rzetelnego wydawnictwa ścisłego naukowo.

Pewne wątpliwości wnikliwego czytelnika budzić może już brak na stronie tytułowej autorów i konsultantów naukowych tak fundamentalnego dzieła. Krótką Przedmowe na str. 5 sygnuje po prostu ,Wydawnictwo Naukowe PWN”. Na stronie 4 mamy podanych „Wydawców” (?, Beata Lewandowska-Kaftan, Danuta Borowska-Mostafa), Redaktora Prowadzącego (Bartłomiej Kaczorowski), Redakcję Kartograficzną, osoby odpowiedzialne za wybór i opracowanie ilustracji, czy redakcję map, nawet za sprawy techniczne - ale nikt nie sygnuje swoim nazwiskiem koncepcji tego dzieła. A rzut oka na zawartość tomów dotyczących Azji wyraźnie wskazuje, że bez wysoko kwalifikowanych specjalistów - jakich przecież w Warszawie nie brakuje - nie sposób zrobić porządnie takiego wydawnictwa samymi siłami redaktorów wydawnictwa. Rezultatem jest bowiem - mówiąc metaforycznie - aż kilka łyżek dziegciu w tej beczułce miodu.

Przede wszystkim zasadnicze wątpliwości budzi podział Azji. ONZ, jej agendy i wydawnictwa, a także instytucje międzynarodowe oraz współczesne publikacje naukowe wyróżniają Azję Wschodnią - dzieloną jeszcze na Północno-Wschodnią (Chiny, oba państwa koreańskie, Japonia i Mongolia) i Południowo-Wschodnią (10 państw na południe od Chin i na wschód od byłych kolonialnych Indii; nazwę tę wprowadzono podczas II wojny światowej, dlatego tak ten region zdefiniowano). Drugim wielkim regionem jest Azja Południowa (Indie, Pakistan, Bangladesz, Sri Lanka, Nepal, Bhutan). Bardziej 
skomplikowana jest sprawa Azji Zachodniej, do której dodaje się często Środkową, chociaż nieraz używa się też mniej precyzyjnego terminu „Środkowy Wschód” (Middle East). Generalnie zalicza się do tego regionu państwa leżące na zachód od dawnych kolonialnych Indii, czyli od współczesnej granicy afgańsko-pakistańskiej. Do niego zalicza się także często ciążące wyraźnie ku temu regionowi obecne post-sowieckie republiki Azji Środkowej, chociaż należą one do Rady Europy, OBWE i innych ciał europejskich. Wspomnieć trzeba, że do Azji Wschodniej dodaje się często Australię i Oceanię - pisząc o regionie Azji Wschodniej i Pacyfiku. Tak podaje swe statystyki Bank Światowy, Międzynarodowy Fundusz Walutowy, OECD itd.

Zarzucono natomiast już w świecie od dawna poetycki „Wschód” - ukochany jeszcze przez romantyków, czy „Daleki Wschód” - z epoki kolonialnego zwierzchnictwa nad Azją Londynu i Paryża. Amerykanie, którzy zaczęli budować swa dominację w świecie po II wojnie światowej, słusznie zwracali uwagę, że to termin jaskrawo europocentryczny i dla nich Chiny stanowiłyby „Bliski Zachód”, a rejon Zatoki Perskiej „Daleki Zachód”. Od lat 60. XX w. utrwalił się zatem podział wszystkich kontynentów na regiony, zależnie od ich położenia na danym kontynencie - na część wschodnia, zachodnią, południową itd. Dlatego też wyróżniamy podobnie Europę - zachodnią, wschodnią, czy południową.

Osoby, które zredagowały ten Atlas zaoferowały nam natomiast podział przedziwny, łamiący ustalone zwyczaje i reguły, sprzeczny ze współczesnym życiem międzynarodowym i logika, chyba tylko dlatego, aby każdy zeszyt zamknąć na 96 stronach. Otóż w zeszycie „Azji Wschodniej” (t. 7) umieszczono Chiny, Tajwan (o jego statusie napiszemy poniżej), oba państwa koreańskie, Japonię i Mongolię (czyli Azję Północno-Wschodnią), a dołączono do nich kraje dawnych Indochin francuskich, czyli Wietnam, Laos i Kambodżę, jak też Filipiny - czyli łącznie 4 państwa zaliczane do Azji Południowo-Wschodniej. W zeszycie „Azji Południowej” (w t. 8) zamieszczono natomiast - nie wiadomo dlaczego - pozostałe państwa Azji Południowo-Wschodniej (Indonezję, Malezję, Brunei, Singapur, Tajlandię i Birmę przemianowaną przez juntę wojskową na Myanmar). Jednak na zachodzie wyłączono z tego regionu Pakistan, bo przyłączono go - prawem kaduka - do „Azji Środkowo-Zachodniej". Z kolei z tego regionu (t. 9) wyłączono Kazachstan, bo doliczono go do „Europy Wschodniej i Azji Północnej” (t. 6). Ma to o tyle uzasadnienie, że istotnie część jego terytorium leży na zachód od Rzeki Ural, więc bywa on zaliczany do państw Europy (ale pamiętajmy, że nie zalicza się jednak Turcji do Europy, chociaż jej kawałek leży na europejskim brzegu Bosforu). Te kwestie Azji Zachodniej i Środkowej pominę jednak, bo nie jest to moja dziedzina.

Takie grupowanie państw z użyciem powszechnie przyjętych nazw regionów geograficznych, ale łamiące uznaną terminologię i praktykę życia międzynarodowego, tylko miesza czytelnikom w głowie. Rzecz jest tym groźniejsza, iż w Polsce ignorancja na temat Azji jest doprawdy i tak porażająca. Nagminnie używa się wciąż - nawet w publikacjach naukowych - przestarzałego i europocentrycznego terminu Daleki Wschód. Ostatnio mnożą się zaś przypadki - nawet w najszacowniejszych gazetach i TVP - zaliczania Chin i Korei, a już niemal zawsze Tajwanu, do „Azji PołudniowoWschodniej”. Jeśli redaktorzy chcieli przygotować równe objętościowo zeszyty łamiąc 
podziały geograficzne (przypomnijmy: w publikacji zatytułowanej „atlas”), trzeba było wymyślić jakieś inne określenia, typu: Chiny i ich sąsiedzi; Indie i kraje pobliskie itp.

Wprawdzie w Przedmowach do poszczególnych zeszytów dodano pewne wyjaśnienia, ale są one nieprecyzyjne, a miejscami wręcz bałamutne. Np. stwierdza się, że t. 7 ,został w całości poświęcony Azji Wschodniej czyli Dalekiemu Wschodowi”. Ten ostatni termin miał jednak dużo szerszy zakres i obejmował nie tylko wszystkie kraje Azji Wschodniej (z Południowo-Wschodnią włącznie), ale często nawet Indie i Pakistan. W przedmowie tej wspomina się wprawdzie, że cztery kraje należą do Stowarzyszenia Azji PołudniowoWschodniej, ale przynależność do tego stowarzyszenia to jednak co innego niż do regionu Azji Południowo-Wschodniej, a dodajmy, że dopiero od niedawna przynależą doń wszystkie kraje regionu, gdyż poszczególne kraje przyjmowano w kilku etapach. Podobnie w Przedmowie do t. 8 wspomina się, że obejmuje on kraje Azji Południowej i PołudniowoWschodniej, ale znowu nie precyzuje się, jakie należą do którego regionu. Bardzo dziwne jest też wyliczenie krajów, ,które z różnych powodów nie weszły w połowie XX w. w skład niepodległych Indii”, gdzie znalazła się - nie wiadomo dlaczego - np. Birma. Wprawdzie istotnie była ona przez pewien czas podporządkowana w kolonialnej strukturze wicekrólowi Indii, ale już na początku lat 30. XX w. wywalczyła sobie status samodzielnej kolonii, a kiedy powstawała Republika Indii była już państwem niepodległym, nie należącym nawet do Brytyjskiej Wspólnoty Narodów. Jeszcze większą bzdurą jest oddzielne wyliczanie krajów Azji Południowo-Wschodniej, jakby Birma do nich nie należała.

Wspomnieć można, że istotnie zdarzało się dawniej nieco węższe stosowanie terminu Azja Wschodnia. Zaliczano wtedy do niej państwa rozwijające się w sferze oddziaływań chińskich (tj. same Chiny, Koreę, Japonię i Wietnam, czy nawet Mongolię), lecz to miało przynajmniej walor pewnej wspólnoty tradycji kulturowych. Terminologia zaś zastosowana w Atlasie łamie i ten koncept. Dodajmy, że wraz z postępującą integracją państw Azji Południowo-Wschodniej w ramach organizacji ASEAN, współcześnie nie wyłącza się już jednak z tego regionu Wietnamu, istotnie w przeszłości bliżej związanego z Chinami. Oto zatem podstawowy zarzut wobec tej publikacji: całkowity mętlik w podziale Azji na regiony.

Koncepcja przedstawienia poszczególnych państw i ich opisy nastręczają natomiast dużo mniej wątpliwości. Zasługuje na uznanie wszechstronność i nowoczesność prezentacji (choć oczywiście nad niektórymi szczegółami można by dyskutować). Przy nagłówku znajduje się np. ilustracja flagi i godła danego państwa, a także podaje się numer kierunkowy w automatycznym ruchu telefonicznym, oznaczenie państwa na samochodach, czy w adresach internetowych, jak też jeden adres internetowy z oficjalną informacją o tym kraju. Nasuwa się jedynie wątpliwość, czy nie lepiej było podawać różnicy czasu miejscowego wobec Warszawy (wszak jest to publikacja polska!), zamiast odniesienia do czasu GMT, który jest dużo mniej znany. Oczywiście ma on jeden podstawowy walor: jest stały i nie podlega zmianie na „czas letni”, lecz można było tę kwestię rozwiązać inaczej. W formie tabeli podaje się podstawowe dane o każdym państwie (nazwa oficjalna, stolica, granice, główne miasta, powierzchnia, ludność, język urzędowy, waluta, święto państwowe, ustrój, podział administracyjny), co bezsprzecznie jest użyteczne. Jednak dołączenie tu głowy państwa i szefa rządu nie wydaje się zasadne, gdyż szybko się one dezaktualizują. W tekście informacji o sytuacji politycznej - kończącej się na konkretnej dacie - miałoby to sens, ale nie w podstawowych danych o kraju. 
W formie dość obszernych artykułów przedstawia się warunki naturalne (z wyróżnieniem klimatu, wód, świata roślinnego, zwierzęcego i problemów ochrony środowiska), historię doprowadzoną niemal do momentu publikacji, ustrój polityczny i współczesne partie polityczne. Uzupełnia to $\mathrm{w}$ formie tabeli wyliczenie jednostek administracyjnych (z podaniem ich obszaru i liczby mieszkańców), zestawienie obiektów danego kraju wpisanych na listę Światowego Dziedzictwa Kulturalnego i Przyrodniczego - co daje pewne wyobrażenie o najważniejszych zabytkach i najciekawszych miejscach. Dołączono krótkie artykuły o gospodarce $\mathrm{z}$ rozmaitymi danymi ujętymi w przystępnej formie graficznej. Na szczególne podkreślenie zasługuje podawanie tu wysokości ,,produktu krajowego brutto” (PKB) w przeliczeniu na mieszkańca (w USD) według wskaźnika realnej siły nabywczej (PPP - Purchase Power Parity) wprowadzonego przez Bank Światowy dla uściślenia porównań międzynarodowych. Daje on dużo lepszą orientację o rozwoju gospodarczym danego kraju niż dane oparte na oficjalnych przelicznikach bankowych kursu danej waluty, jakie wprowadzają w błąd, szczególnie w przypadku gospodarek o kursie regulowanym przez państwo. $\mathrm{Z}$ atlasu tego czytelnik może się więc dowiedzieć, na przykład, że w 2004 r. w Chinach dochód ten wynosił 5.600 USD, w Mongolii - 1.900, w Kambodży - 2.000, w Republice Korei - 19.200, a w Japonii - 29.400.

Jednakże wartość PKB państwa podaje się w Atlasie wedle oficjalnego kursu waluty krajowej wobec dolara - co nieraz, zwłaszcza w odniesieniu do krajów rozwijających się - bardzo fałszuje realia. W rezultacie np. podany tu PKB Chin wynosi w przybliżeniu 1/3 PKB Japonii, podczas gdy wyliczany według wskaźnika PPP byłby w przybliżeniu większy o 1/3 od PKB Japonii. W stosunku do Stanów Zjednoczonych podany tu PKB Chin stanowi w przybliżeniu $1 / 8$ ich produktu krajowego, a wedle realnej siły nabywczej - aż 2/3, co zasadniczo zmieniałoby obraz realnego układu sił gospodarczych. Dlatego w odpowiednich publikacjach ekonomicznych Banku Światowego, czy w analizach CIA, już od ponad 10 lat Chiny zajmują drugie miejsce po Stanach Zjednoczonych, a Japonia - trzecie. Wtedy oczywiście i diagramy o miejscu danej gospodarki w świecie, zamieszczone w Atlasie, też wyglądałyby inaczej. A sprawa dotyczy wielu krajów. Dla ilustracji problemu porównajmy np. PKB kilku krajów z tego Atlasu (2004) i najnowsze dane Banku Światowego według przelicznika PPP (2005) - w mld USD.

\begin{tabular}{|l|c|c|}
\hline & Atlas & Bank Światowy PPP \\
\hline Chiny & 1649,3 & 8572,6 \\
\hline Indie & 691,9 & 3815,5 \\
\hline Indonezja & 257,6 & 847,4 \\
\hline Japonia & 4623,4 & 3943,7 \\
\hline Korea Płd. & 679,8 & 1056,0 \\
\hline Malezja & 117,8 & 274,8 \\
\hline Tajlandia & 163,5 & 549,2 \\
\hline Wietnam & 45,2 & 254,0 \\
\hline
\end{tabular}


Co jeszcze gorsze, w Atlasie nie podaje się przy tych liczbach, na jakich przelicznikach są one oparte. Istotnie, Bank Światowy także podaje PKB wg przeliczników nominalnych, lecz są one cenione głównie przez ekonomistów zajmujących się krajami wysoko rozwiniętymi. Sprawa metod liczenia jest niewątpliwie dość skomplikowana, ale rozwiązanie tu przyjęte - jest fatalne. Można wspomnieć, że same Chiny dość konsekwentnie obstają przy przelicznikach opartych na oficjalnych przelicznikach ich banków, gdyż starają się zaniżać swe dane, by jak najdłużej korzystać z przywilejów „kraju rozwijającego się”. Stany Zjednoczone coraz głośniej domagają się rezygnacji z tego oficjalnego zaniżania wartości chińskiej waluty. W zgodzie ze swym stanowiskiem, Chiny zatem głośno się cieszą, że awansują np. z szóstej na piątą gospodarkę świata, co powtarzają bezrozumnie rozmaite polskie gazety, nie zdając sobie sprawy, że od ponad 10 lat Chiny już są drugie i doganiają Stany Zjednoczone (PKB USA w 2005 r. wyniósł 12409 bilionów USD, a Chin 8572 bilionów). Można by więc zapytać ironicznie, dlaczego polskie wydawnictwo upowszechnia akurat propagandowe stanowisko chińskie, pomijając protesty amerykańskie, choć wypacza to oczywiście nie tylko sytuację tego jednego kraju.

Inne dane gospodarcze nie budzą istotniejszych zastrzeżeń. Wartościowe są np. dane dotyczące struktury PKB, infrastruktury transportowej, czy turystyki, jak też łączności (telefonów stacjonarnych, komórkowych, internetu na 1000 mieszkańców) - co daje pewne wyobrażenie o rozwoju danego kraju. Dane o handlu zagranicznym pokazują głównych partnerów. Znajdziemy tu także dane o głównych gałęziach gospodarki i o bankowości. W wydzielonej rubryce podaje się podstawowe dane demograficzne (z bardzo istotną strukturą wiekową mieszkańców), a obok tego najważniejsze czasopisma, agencje prasowe, stacje radiowe i telewizyjne.

Wśród danych demograficznych podana jest jednak „struktura religijna” budząca szczególnie w przypadku Azji Wschodniej - wielkie wątpliwości. Jak można sądzić, dane wzięto z jakiegoś informatora o całym świecie, którego autorzy posiadali nikłą wiedzę o sprawach religijnych Azji Wschodniej. Otóż w trzech religiach monoteistycznych uformowanych w basenie Morza Śródziemnego (jak też w ich odłamach i sektach powstałych na ich gruncie) istnieją,,wspólnoty wyznawców” i rytuały przyjmowania do nich nowych członków (jak chrześcijański chrzest). Oparte są też one na zasadzie ekskluzywności, tj. wyznawać można tylko jedną z nich. W pewnym przybliżeniu podobne zjawiska występują także w Indiach. Natomiast w Azji Wschodniej nie ma takich zamkniętych wspólnot, ani rytuałów przyjmowania do nich, a dominuje zasada synkretyzmu. Nie ma zatem sposobu, by policzyć „wyznawców religii miejscowych”, a ta sama osoba w różnych momentach swego życia, a nawet jednego dnia, może praktykować buddyzm, taoizm, konfucjański kult przodków i składać ofiary bóstwom z kultów ludowych. Nierzadko nawet świątynie trudno precyzyjnie zaliczyć do którejś religii, a kwestią sporną jest także, co stanowi „religię” i jak wydzielać te miejscowe systemy wierzeń i praktyk. Oto kilka pytań dla ilustracji problemu. Czy konfucjanizm jest religią? Czy tzw. „wierzenia ludowe” są religią i jak je zakreślać? Do czego zaliczyć kult przodków? Czy buddyzm Hinayana jest religia, czy raczej doktryną filozoficzno-moralną? Religijna natura buddyzmu Mahayana nie budzi natomiast większych wątpliwości. Czy feng-shui, szamanizm i inne tego typu 
praktyki oraz wierzenia „niezinstytucjonalizowane” zaliczać można do religii? Jeśli tak, to do jakiej? (O sprawach tych pisałem w t. 6 Azji-Pacyfiku).

$\mathrm{W}$ rezultacie sytuacja religijna $\mathrm{w}$ wielu krajach regionu została zupełnie zafałszowana. W Chinach np. 50\% ludności to rzekomo „bezwyznaniowi”, a 29\% przyjmować ma „tradycyjne chińskie systemy etyczno-religijne” (czyli co?). Buddystów jest jakoby tylko $8 \%$. Nie wspomina się przy tym, że buddyzm występuje tam w trzech zasadniczo odmiennych formach: Mahayany, Wadżrajany (czyli lamaizmu) i Hinayany. Taoistów zaś nie wymienia się wcale, choć to jedna $z$ oficjalnie uznawanych „religii” i jedna z popularniejszych.. Pojawia się jeszcze zagadkowa kategoria „tradycyjnych religii plemiennych” (4\%!), choć struktur plemiennych w Chinach współczesnych trzeba by szukać ze świecą! Chrześcijanie i muzułmanie nie budzą wątpliwości (7\% i 2\%), choć liczba tych ostatnich jest chyba znacznie zaniżona. Przy opisie Tajwanu w Atlasie pojawiają się taoiści, a znikają ,tradycyjne chińskie systemy etyczno-religijne”, chociaż tamtejszy system religijny nie różni się zasadniczo. Można jedynie stwierdzić, że tam tradycyjne praktyki religijne przetrwały bez szwanku. Nie podaje się przy Tajwanie „religii plemiennych”, chociaż akurat tam są aborygeni austronezyjscy, których można by zaliczyć do ich wyznawców. W Japonii shintoiści i buddyści podani są razem - co jest rozsądne, bo ich wyznawców nie da się rozdzielić - i stanowić mają łącznie 91\%. Nie ma zaś wcale „bezwyznaniowych”, chociaż sytuacja w Chinach i Japonii wykazuje wiele podobieństw. W Kambodży buddyści stanowić mają $85 \%$ ludności, ale nie wspomina się nawet, że chodzi o zupełnie inny - niż w przypadku Chin, Japonii, czy choćby sąsiedniego Wietnamu - odłam buddyzmu: Hinayanę. A są to o wiele większe różnice niż w przypadku katolicyzmu i prawosławia. Religia jest niewątpliwie kluczowym elementem kultury danego kraju, styka się z nią niemal każdy turysta - jak można więc było tak beztrosko potraktować tę sprawę?

Dodać jednak trzeba, że artykuły o historii są napisane - na ogół - poprawnie i nie budzą zasadniczych zastrzeżeń, choć zawodowy historyk mógłby się spierać o rozmaite detale. Ta pozytywna ocena dotyczy nawet historii Tajwanu zwykle niemiłosiernie naciąganej w naszej prasie dla wątpliwych ideologicznych korzyści. Oczywiście są w Atlasie teksty słabsze i lepsze. W przypadku Wietnamu mamy np. do czynienia z jaką́s nacjonalistyczno-antychińską wizjąjego dziejów, a jedynymi faktami historycznymi wymienianymi w Atlasie są w istocie kolejne walki z wojskami chińskimi. Nie wspomina się zaś o tym, że i Wietnamczycy prowadzili jakieś wojny z innymi sąsiadami, w których wyniku terytorium kraju zwiększyło się aż kilkakrotnie. M.in. unicestwiono całe państwo Czampę i włączono do Wietnamu dawne ziemie imperium khmerskiego na południu. Oczywiście poza wojnami i powstaniami także coś jeszcze się działo! W przypadku Laosu nie wspomina się, że ludność jego należy do grupy tajskiej i przywędrowała na te tereny w wyniku wielkich migracji ludów tajskich z południowego pogranicza dzisiejszych Chin. Oczywiście średniowieczne księstwa, z jakich powstało to państwo, były właśnie księstwami tajskimi, które zachowały niepodległość od poprzedników dzisiejszej Tajlandii. Pojawia się w tym opisie chyba też za dużo informacji o dawnych państwach z regionu, bez mapy historycznej i dodatkowych objaśnien - trudno zrozumiałych. W przypadku Kambodży upadek imperium khmerskiego wiąże się tutaj jedynie z rozpowszechnianiem buddyzmu, a zanikiem hinduizmu, choć ten ostatni był głównie religią dworską. Kluczowe znaczenie miało właśnie 
przywędrowanie ludów tajskich i tworzenie przez nie swoich państw, co doprowadziło do rozpadu imperium. Uwag mniej czy bardziej szczegółowych można by przedstawić - rzecz jasna - znacznie więcej. Podkreślić jednak warto, że historia tych krajów jest - na ogół - przedstawiana obiektywnie, bez tendencyjnych zakłamań ideologiczno-politycznych częstych w polskich informacjach prasowych.

Pewne wątpliwości może budzić pominięcie w opisach Hongkongu, choć ma on swą odrębną od Chin historię i specyfikę, cieszy się szeroką autonomią, a jest też kluczowym centrum gospodarczym Azji Wschodniej (zamieszczono tylko oddzielnie jego mapkę). Czy należało przedstawiać Tajwan jako „państwo”, takie samo jak inne, jak tu zrobiono? To kwestia dyskusyjna, tym bardziej iż podana tam flaga i godło to symbole całych Chin epoki Kuomintangu, a nie samego Tajwanu (gdyż takich nie ma) i przyjmuje się tam oficjalnie nadal „konstytucję ogólnochińską” z 1947 r., co wyklucza proklamowanie niepodległości Wyspy. Zamierzano wprawdzie zmienić konstytucję, by zmienić w niej nazwę państwa (dziś nazywa się ono wciąż Republiką Chińską), a także granice „terytorium narodowego" (w teorii obejmującego całe Chiny), ale na razie pro-niepodległościowe ugrupowania nie mają wystarczającej większości w parlamencie. Sprawa jest zatem zawikłana i o wiele mniej jednoznaczna niż przedstawia to zazwyczaj prasa polska. Status tej wyspy jest rozmaicie określany, a jej niepodległości od Chin nigdy nawet jeszcze formalnie nie ogłoszono. ONZ i wszystkie wielkie mocarstwa też nie uznają go za odrębne państwo (podobnie jak Polska). Przedstawianie go zatem po prostu jako odrębnego państwa, obok Chin i Japonii, kłóci się po prostu z realiami. Na razie Tajwan można traktować jedynie jako państwo de facto, a nie de iure. Trzeba było poszukać więc jakichś rozwiązań zastępczych. Ale - podkreślam - informacje historyczne i polityczne o tej wyspie podane są obiektywnie i uczciwie.

Wydawnictwo to bardzo uatrakcyjnia spora liczba barwnych i ładnych fotografii. Nad ich doborem można by jednak nieraz dyskutować. Np. na dużej fotografii centrum Jokohamy widnieje akurat Ulica Chińska (co jest tam nawet napisane hieroglifami), z charakterystyczną chińska, a nie japońską, bramą na pierwszym planie. A jest to jedyna fotografia nowoczesnego miasta japońskiego!. Dla profana to może wszystko jedno, ale taki atlas powinien jednak dbać o profesjonalizm. Dziwi zaś brak tradycyjnej ulicy japońskiej, np. z Kioto. Trzeba jednak docenić trudność właściwego doboru i wszechstronność tematyki umieszczonych ilustracji.

Oczywiście można by jeszcze dyskutować o rozmaitych innych detalach, ale przyznać trzeba, że w sumie jest to pozycja dość rzetelna i bardzo użyteczna, chociaż z bardzo istotnymi mankamentami. 